\title{
The Influence of Voltage Quality on Asynchronous Motor Performance of EKG Excavator in Open Pit Mines - Vinacomin
}

\author{
Ngo XUANCUONG ${ }^{1, *}$, Do NHU $Y^{2)}$, Tran QUANG HIEU ${ }^{2)}$
}

${ }^{1)}$ School of Engineering and Technology - Hue University, Thua Thien Hue, Vietnam; email: ngoxuancuong@hueuni.edu.vn
${ }^{2)}$ Hanoi University of Mining and Geology, 18 Vien street, Hanoi, Vietnam; email: donhuy@humg.edu.vn; tranquanghieu@humg.edu.vn

http://doi.org/10.29227/IM-2020-02-18

Submission date: 06-03-2020 | Review date: 22-09-2020

\section{Abstract}

At present, in open-pit mining, the main and most important electrical load is the electric excavator, and currently using a variety of EKG excavators. $6 \mathrm{kV}$ electrical network in open pit mining has the characteristics such as long outgoing lines, use high-powered equipment, multiple branches, and increasing use of power electronics on the grid, this reduces the quality of the power supplied to the excavators EKG, resulting in an increase in power losses thereby greatly affecting the performance of the excavators. Previous studies on the quality of the power supplied to the excavator often only mentioned voltage deviations, in addition to this factor, the performance of the excavator is also greatly affected by nonsinusoidal voltage waveforms of the excavator power supply. This paper analyzes the influence of the nonsinusoidal of voltage on the power loss of electric motors used in EKG electric excavators in open pit mining based on the method of electromagnetic analysis and verification on simulation software.

Keywords: power quality, harmonic, nonsinusoidal voltage, EKG excavators

\section{Introduction}

EKG excavators are designed to dig and excavate largesized minerals in open-pit mines of Vinacomin (Bui \& Drebenstedt, 2004; Hai, 2016; Zenkov et al., 2018). The EKG-5A excavator is a modification of the previous models of EKG4.6B, EKG-4.6A, EKG-4.6 issued by Uralmashzavod. EKG excavator uses $6 \mathrm{kV}$ three-phase electric network frequency of $50 \mathrm{hz}$, includes many types of asynchronous motors (AM) with large power (Хисматуллин, 2018).

$6 \mathrm{kV}$ electrical network in open pit mining has the characteristics such as long outgoing lines, use high-powered equipment, multiple branches, and increasing use of power electronics on the grid, this reduces the quality of the power supplied to the excavators EKG, resulting in an increase in power losses thereby greatly affecting the performance of the excavators. Studying the effects of the mains voltage on an $\mathrm{AM}$ is essential to determine its performance.

Voltage unbalance (VU) will lead to an increase in temperature of AM and shorten engine life, and under-VU often causes the worst temperature rise (Lee, 1999). VU causes more load to the supplier and additional cost to consumers. A deficiency such as VU in the voltage source can lead to problems such as excessive loss, overvoltage, mechanical oscillation and interference with control electronics (Mirabbasi et al., 2009). VU has a marked effect on losses in AM (Kersting \& Phillips, 1997). Complex VU factor angle increases the winding temperature, and reduced coefficient of AM is supplied with VU (Gnacinski, 2008; Wang, 2001). The power factor of an AM is inversely proportional to the positive sequence, and performance is also proportional to the positive sequence (Lee, 1999; Dekhandji et al., 2017).

The PWM supply of the inverter causes additional losses, which is manifested as an increase in temperature in the AM. Common losses are mitigated when the switching frequency is higher in the PWM supply. The increase in temperature due to additional losses is significant compared to machines operated from sinusoidal sources (Ding \& Mi, 2011).

AM supplied with an electrical system containing high harmonic voltages will experience increased vibration. The same is true for motors driven by a voltage source converter, depending on the harmonic level, a motor will have a very rich vibration spectrum (Yacamini \& Chang, 1995).

Power quality includes harmonic voltages and currents, poor power factor and VU. Above analysis clearly shows the influence of VU on the AM, to get a closer look at the influence of voltage quality on AM, this paper focuses on the influence of voltage harmonics or nonsinusoidal voltage on AM.

Article content gives a method to build a simulation model for AM on EKG excavators and analyzing the influence of nonsinusoidal voltage on power losses and some other characteristics of AM used in EKG excavators in open mines, and make recommendations to improve their performance.

\section{Research models}

\subsection{Motor parameters}

The AM chosen for this study is M-G set main drive motor $-250 \mathrm{~kW}$ of EKG-5A, has the nominal data and other characteristic sizes indicated in Tab. 1 (Хисматуллин, 2018; Mashinform). These AM windings are connected in a threewire Y-configuration with isolated neutral.

The simulation software is Matlab-Simulink version R2014a. The paper uses a three-phase AM model in the library as a research motor. The parameters included in the model are calculated based on the manufacturer parameters in Tab. One and the program has been presented in Natarajan's research (Natarajan \& Misra, 1989). The simulation parameters of the AM are shown in fig. 2.

In addition to completing the parameters included in the program section using the formula of calculating synchronous speed: 


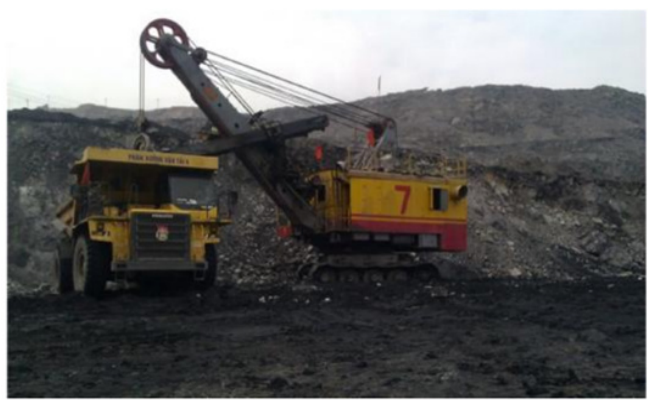

Fig. 1. EKG electric excavators in open-pit mines of Vinacomin (Hai, 2016) Rys. 1. Koparki elektryczne EKG w kopalniach odkrywkowych Vinacomin

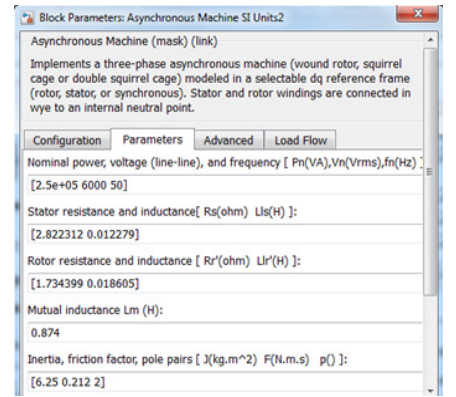

Fig. 2. Simulation parameters of squirrel cage asynchronous motor Rys. 2. Parametry symulacyjne asynchronicznego klatkowego silnika

$N_{s}=\frac{60 \cdot f_{n}}{p}$

where, $f_{n}$ - Frequency of network in Hz; $p$ - Pole pairs.

The formula of calculating rated torque:

$T_{n}=\frac{30 \cdot P_{n}}{\pi \cdot N_{n}}$

where, $\mathrm{P}_{\mathrm{n}}$ - Rated power in $\mathrm{W} ; \mathrm{N}_{\mathrm{n}}$ - Rated speed in rpm.

\subsection{Mathematical model}

The electrical part of AM is represented by a fourth-order state-space model. All stator and rotor quantities are in the dq frame in fig. 3. The physical model considered is linear, inductivities are considered constant, so here the phenomenon of saturation of the magnetic circuit is not considered (Mathworks; Beleiu et al., 2020).

Calculate the power factor PF, taking into account the harmonics, with the following relation:

$$
P F=\frac{P_{i n}}{\sqrt{P_{i n}{ }^{2}+Q_{i n}{ }^{2}}}
$$

where, $\mathrm{P}_{\text {in }}$ - the active input power, in $\mathrm{W} ; \mathrm{Q}_{\text {in }}$ - the reactive input power, in Var.

Mechanical power is calculated by the formula:

$$
P_{-M}=T_{e} \cdot \omega_{m}
$$

where, $\mathrm{Te}$ - the electromagnetic torque, in $\mathrm{Nm}$; $\omega \mathrm{m}$ - the angular velocity of the rotor, in $\mathrm{rad} / \mathrm{s}$.

Mechanical losses are determined with the following formula:

$$
P_{- \text {loss_m }}=F \cdot \omega_{m}{ }^{2}
$$

where, $\mathrm{F}$ - the friction factor, in N.m.s; $\omega_{\mathrm{m}}$ - the angular velocity of the rotor, in $\mathrm{rad} / \mathrm{s}$.

Motor losses mainly occur in the rotor, stator circuit and ferromagnetic loss. In this AM model ignores ferromagnetic loss. Copper loss on the rotor is determined by the formula:

$$
P_{C u 2}=R_{T}^{\prime}\left(I_{T a}^{2}+I_{r b}^{2}+I_{T c}^{2}\right)
$$

where, $\mathrm{I}_{\mathrm{ra}}, \mathrm{I}_{\mathrm{rb}}, \mathrm{I}_{\mathrm{rc}}$ - Rotor current RMS values in a, b, c phase; $\mathrm{R}_{\mathrm{r}}$ - rotor resistor.

Copper loss on the stator is determined by the formula:

$$
P_{C u l}=R_{s}\left(I_{s a}^{2}+I_{s b}{ }^{2}+I_{s c}{ }^{2}\right)
$$

where, $I_{s a}, I_{s b}, I_{s c}$ - Stator current RMS values in a, b, c phase; $\mathrm{R}_{\mathrm{s}}$ - stator resistor.

Finally, we determine the efficiency of AM using the direct method as follows:

$\eta=\frac{P_{-M}-P_{-l o s s-m}}{P_{i n}} .100$

where $\mathrm{P}_{\text {in }}$ - the active input power, in $\mathrm{W} ; \mathrm{P}_{-}{ }_{\mathrm{M}}-$ the total mechanical power of the motor, in $\mathrm{W} ; \mathrm{P}_{\text {loss } \mathrm{m}}-$ the mechanical losses (friction), in W.

\subsection{Modelling and simulation nonsinusoidal voltage wave- forms}

A nonsinusoidal waveform can be constructed by adding two or more sinusoidal waves. The synthesis of a specific nonsinusoidal waveform is a problem of combining signals of appropriate frequency, amplitude and phase. Using the "Thee-Phase Programmable Voltage Source" block in Simulink can create nonsinusoidal waveforms to asynchronous power motors. 
Tab. 1. Parameters of the asynchronous motor

Tab. 1. Parametry silnika asynchronicznego

\begin{tabular}{|l|l|l|}
\hline Symbol & Parameter & Value \\
\hline & Motor name & A4-355L-4 \\
\hline & Motor type & asynchronous motor \\
\hline & Rotor type & single squirrel cage \\
\hline$P_{n}$ & Rated power & $250 \mathrm{~kW}$ \\
\hline$V_{n}$ & Rated line-to-line voltage & $6 \mathrm{kV}$ \\
\hline$f_{n}$ & Frequency & $50 \mathrm{~Hz}$ \\
\hline$N_{n}$ & Rated speed & $1480 \mathrm{rpm}$ \\
\hline$p$ & Pole pairs & 2 \\
\hline$I_{s}$ & Stator full Load current & $29 \mathrm{~A}$ \\
\hline$T_{s t} / T_{n}$ & Starting /rated torque & 1.2 \\
\hline$I_{s} / I_{n}$ & Starting/rated current & 6.0 \\
\hline$T_{b r} / T_{n}$ & Maximum pull out/rated torque & 2.2 \\
\hline$\eta_{n}$ & Rated efficiency & $94.1 \%$ \\
\hline$P F$ & Power factor & 0.88 \\
\hline$J$ & Moment of inertia of the rotor & $6.25 \mathrm{~kg} \cdot \mathrm{m}^{2}$ \\
\hline
\end{tabular}

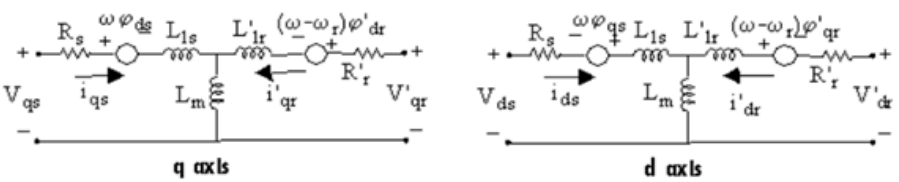

Fig. 3. Model of squirrel-cage asynchronous motor on the reference frame qd (Mathworks) Rys. 3. Model silnika asynchronicznego klatkowego na układzie odniesienia qd (Mathworks)

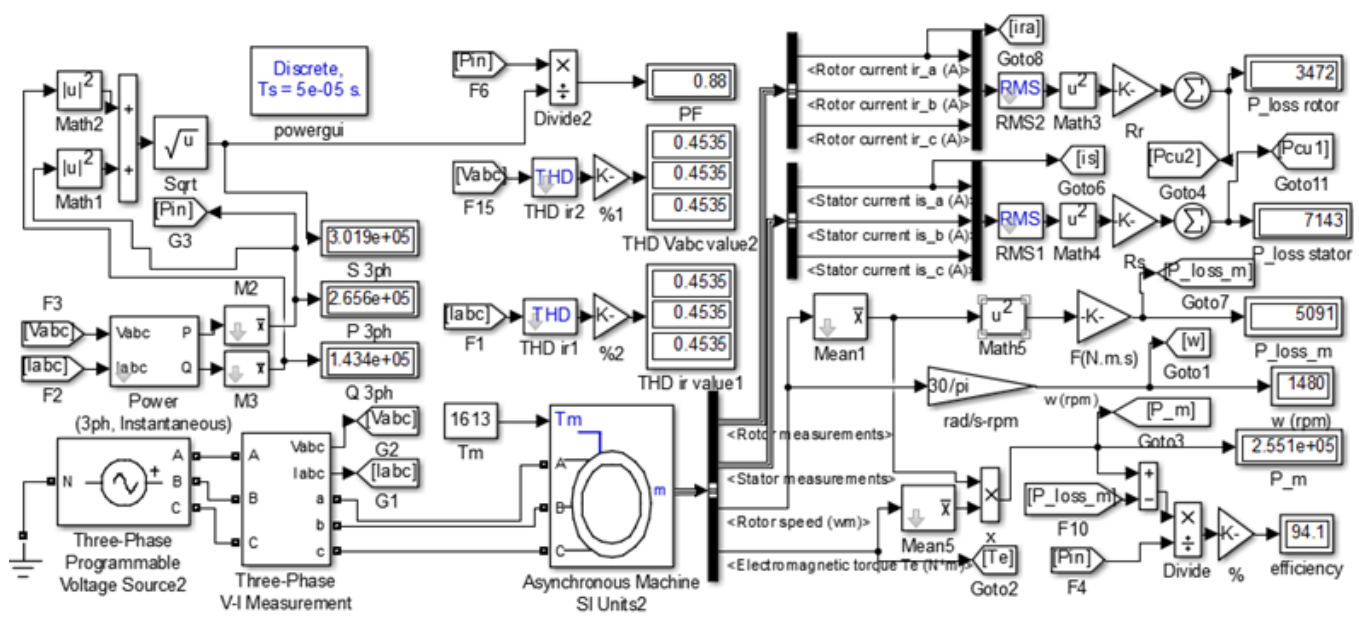

Fig. 4. Research model

Rys. 4. Model badawczy

Harmonics are sinusoidal voltages with frequencies that are integer multiples of the fundamental electrical system frequency. Harmonics has the positive-sequence $\left(\mathrm{k}_{\mathrm{p}}=3 \mathrm{n}+1\right)$, negative-sequence $\left(k_{n}=3 n+2\right)$ and zero-sequence $\left(k_{z}=3 n\right)$. In asynchronous motor, when motor windings are connected in a three-wire Y-configuration with isolated neutral, circulation of zero-sequence current harmonics is null.

The model shown in fig. 4 illustrates the simulated AM model in MATLAB/Simulink. Block "Asynchronous Machine" (single squirrel cage) operates in motor mode.

With the following initial hypotheses to study asynchronous motor behaviour in nonsinusoidal of voltage:

- The initial reference situation is when the stator is provided with a symmetrical sinusoidal voltage, at grid frequency, the motor operates stably at a specified torque and constant speed.

- The nonsinusoidal voltage is generated by adding harmonic components, with 5 th, 7 th, 11 th, and 13 th order har- monics and both having equal amplitude percentages, so that the voltage total harmonic distortion ( $\mathrm{THDu}$ ) applied to the motor is within the ranges $\{0,1 \%, 3 \%, 5 \%, 7 \%, 10 \%, 15 \%\}$.

\section{Results}

In order to evaluate the effect of nonsinusoidal voltage on asynchronous motors, we give the parameters of motors operating with sinusoidal voltages, simulation results with different load levels are given as Table 2.

In figure 5, show the dependence of the percentage of copper loss on the stator, rotor, mechanical power loss and mechanical power relative to the power put into the value of the load moment.

In figure 6, it is the transient characteristic of the asynchronous motor when working with the standard sinusoidal voltage. Figure $6 \mathrm{a}$ is the characteristic of the electromagnetic moment (Te) and velocity (w), Figure $6 \mathrm{c}$ is the characteristic of the active power $(\mathrm{Pin})$, mechanical power $\left(\mathrm{P}_{\mathrm{m}}\right)$, mechani- 
Tab. 2. Typical parameters of an asynchronous motor in symmetry and sinusoidal voltages

Tab. 2. Typowe parametry silnika asynchronicznego w napięciach symetrycznych i sinusoidalnych

\begin{tabular}{|l|r|r|r|r|r|r|r|r|}
\hline \multirow{2}{*}{ Parameter } & \multicolumn{9}{|c|}{ Motor Load, Nm } \\
\cline { 2 - 9 } & 0 & 160 & 320 & 640 & 806 & 960 & 1613 & 2016 \\
\hline$P_{\text {cul }}, \mathrm{W}$ & 1312 & 1382 & 1560 & 2244 & 2775 & 3378 & 7143 & 10490 \\
\hline$P_{\text {cu } 2}, \mathrm{~W}$ & 1.356 & 45.88 & 153.9 & 563.8 & 880.2 & 1238 & 3472 & 5456 \\
\hline$N, \mathrm{rpm}$ & 1500 & 1498 & 1496 & 1492 & 1490 & 1488 & 1480 & 1475 \\
\hline$T_{e}, \mathrm{Nm}$ & 33.29 & 193.3 & 353.2 & 673.1 & 839.1 & 993 & 1646 & 2049 \\
\hline$P_{\text {loss } m, \mathrm{~W}}$ & 5228 & 5215 & 5202 & 5175 & 5161 & 5148 & 5091 & 5055 \\
\hline$P_{\text {in }}, \mathrm{W}$ & 6541 & 31730 & 57040 & 108000 & 134600 & 159300 & 265600 & 332300 \\
\hline$Q_{\text {in }}, \mathrm{VAr}$ & 129200 & 128900 & 129000 & 130300 & 131500 & 133000 & 143400 & 153100 \\
\hline$P_{m}, \mathrm{~W}$ & 5228 & 30310 & 55330 & 105200 & 130900 & 154700 & 255100 & 316400 \\
\hline$P_{F}$ & 0.05057 & 0.239 & 0.4043 & 0.6381 & 0.7152 & 0.7677 & 0.88 & 0.9082 \\
\hline$\eta, \%$ & 0 & 79.08 & 87.88 & 92.62 & 93.46 & 93.88 & 94.10 & 93.69 \\
\hline THDu & 0.4535 & 0.4535 & 0.4535 & 0.4535 & 0.4535 & 0.4535 & 0.4535 & 0.4535 \\
\hline THDi & 0.4535 & 0.4535 & 0.4535 & 0.4535 & 0.4535 & 0.4535 & 0.4535 & 0.4535 \\
\hline
\end{tabular}

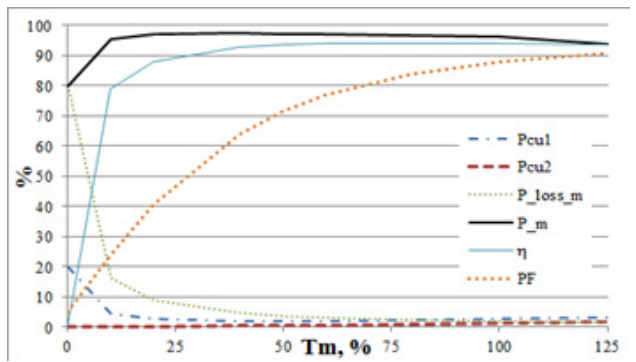

Fig. 5. Dependence of power on load moment

Rys 5. Zależność mocy od momentu obciążenia

cal power loss $\left(\mathrm{P}_{\_}\right.$loss_m $\mathrm{m}$, copper loss on the stator $\left(\mathrm{P}_{\text {cu1 }}\right)$, copper loss on the rotor $\left(\mathrm{P}_{\mathrm{cu}}\right)$. It is corresponding to figure 7 in the case of the motor working under nonsinusoidal voltage, with $5 \%$ voltage THD of $5 \% 5$ th harmonics compared to the base voltage.

The simulation results with cases of nonsinusoidal source voltage are concentrated in Table 3. The values in the table correspond to the operation of the motor in the stable mode when the load on the motor shaft (Tm) is $1613 \mathrm{Nm}$. The mechanical power loss, mechanical power, electromagnetic torque, rotor speed values are equivalent to those when the motor is provided with a sinusoidal voltage.

\section{Discussion}

\subsection{Copper losses}

The copper losses in the rotor and stator circuits increase as the nonsinusoidal voltage increases. The fifth harmonic increases the largest copper loss in the asynchronous motor; the higher harmonic components have less effect on the copper loss. Therefore it should be noted limited 5th harmonic components in the electricity network to the motor.

\subsection{THD of the stator current and torque ripple}

Assessing the influence of the nonsinusoidal voltage on current stator THD (THDi) is given in figure 9. It is obvious that the higher lever of nonsinusoidal voltage or the higher the THDu, the bigger the THDi, the greater the effect of the fifth harmonic. Within the scope of consideration, the THDi is linearly proportional to the THD voltage.

Torque ripple is defined as the percentage of the difference between the maximum torque and the minimum torque compared to the average torque. Figure $9 \mathrm{~b}$ shows the influence of the nonsinusoidal voltage on the torque ripple of the rotor.
Obviously, the larger the THDu, the larger the torque ripple and the fifth harmonic cause the greatest vibration compared to the rest. However, when the applied voltage contains the positive-sequence and negative-sequence harmonic, the torque ripple is significantly reduced, in the case of 11 th and 13th harmonics, the torque ripple increases insignificantly when THDu is high.

\subsection{Power factor and efficiency}

When the nonsinusoidal input voltage appears, the power factor of the asynchronous motor changes. When the positive-sequence and negative-sequence harmonic is matched simultaneously, the power factor is almost constant. The negative-sequence harmonic (H5, H11) increases the power factor of motor, while the positive-sequence $(\mathrm{H} 7, \mathrm{H} 13)$ reduces the power factor of the motor.

When the nonsinusoidal input voltage appears, the asynchronous motor efficiency changes. When the input voltage has a 5th harmonic component, the efficiency of the motor tends to decrease, and when there are a 7th and other harmonic components, the efficiency increases significantly.

\section{Conclusion}

In this article, we proposed a method to build a simulation model for typical asynchronous motors on EKG electric excavators and analyzed the influence of nonsinusoidal voltage on power losses, THD of the stator current, torque ripple, power factor and efficiency of asynchronous motors used in EKG electric excavators in open mines.

The 5th harmonic increases the largest copper loss, torque ripple and power factor in the asynchronous motor; the higher harmonic components have less effect on the copper loss. When the applied voltage contains the positive-sequence and 

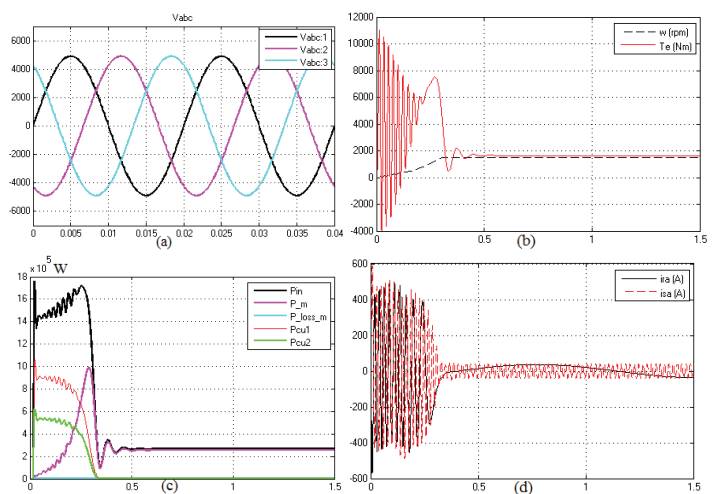

Fig. 6. Transient characteristic of an asynchronous motor with sinusoidal voltages Rys. 6. Charakterystyka przejściowa silnika asynchronicznego przy napięciach sinusoidalnych

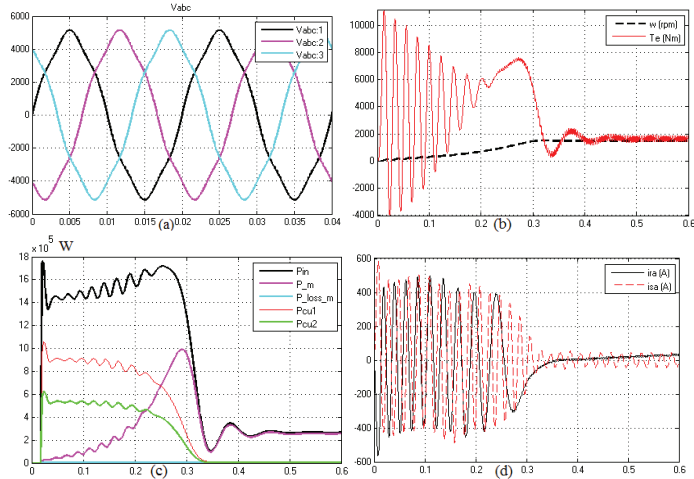

Fig. 7. Transient characteristic of an asynchronous motor with nonsinusoidal voltage and 5\% voltage THD Rys. 7. Charakterystyka przejściowa silnika asynchronicznego przy napięciu niesinusoidalnym i 5\% THD napięcia

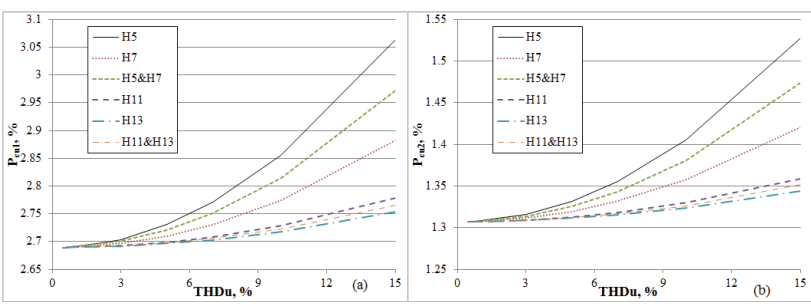

Fig. 8. The copper losses in the stator (a) and rotor (b) circuits Rys. 8. Straty miedzi w obwodach stojana (a) i wirnika (b)

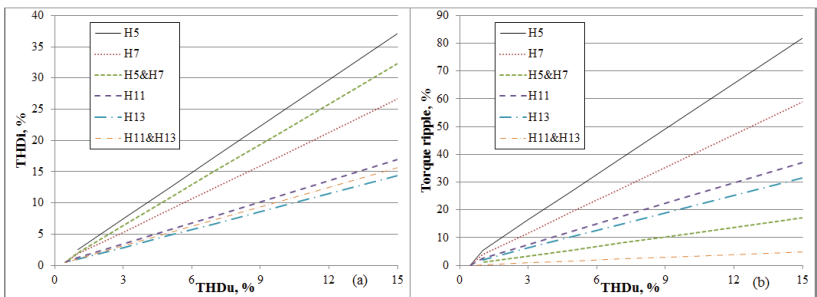

Fig. 9. Dependence of THDi (a) and torque ripple (b) on the nonsinusoidal voltage Rys. 9. Zależność THDi (a) i tętnienia momentu (b) od napięcia niesinusoidalnego

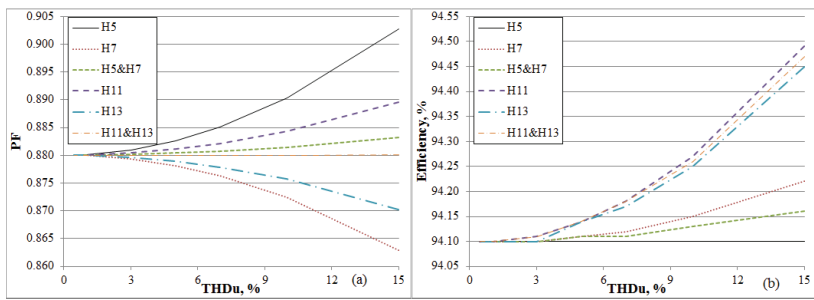

Fig. 9. Dependence of THDi (a) and torque ripple (b) on the nonsinusoidal voltage Rys. 9. Zależność THDi (a) i tętnienia momentu (b) od napięcia niesinusoidalnego 
Tab. 3. Simulation results for nonsinusoidal source voltage cases

Tab. 3. Wyniki symulacji dla przypadku niesinusoidalnego napięcia

\begin{tabular}{|c|c|c|c|c|c|c|c|}
\hline & THDu, $\%$ & 15 & 10 & 7 & 5 & 3 & 1 \\
\hline \multirow{8}{*}{$\begin{array}{l}5^{\text {th }} \text { order } \\
\text { harmonic } \\
\quad(\mathrm{H} 5)\end{array}$} & Weight, \% & 15 & 10 & 7 & 5 & 3 & 1 \\
\hline & $P_{c u l}, \mathrm{~W}$ & 8137 & 7585 & 7360 & 7254 & 7183 & 7148 \\
\hline & $P_{c u 2}, \mathrm{~W}$ & 4058 & 3733 & 3600 & 3537 & 3496 & 3475 \\
\hline & Torque ripple, $\%$ & 81.81 & 54.54 & 38.18 & 27.27 & 16.36 & 5.454 \\
\hline & $P_{\text {in }}, \mathrm{W}$ & 265600 & 265600 & 265600 & 265600 & 265600 & 265600 \\
\hline & $P F$ & 0.9028 & 0.8903 & 0.8851 & 0.8826 & 0.881 & 0.8801 \\
\hline & $\eta, \%$ & 94.1 & 94.1 & 94.1 & 94.1 & 94.1 & 94.1 \\
\hline & THDi, $\%$ & 37.19 & 24.8 & 17.37 & 12.41 & 7.454 & 2.521 \\
\hline \multirow{8}{*}{$\begin{array}{l}7^{\text {th }} \text { order } \\
\text { harmonic } \\
(\mathrm{H} 7)\end{array}$} & Weight, $\%$ & 15 & 10 & 7 & 5 & 3 & 1 \\
\hline & $P_{c u l}, \mathrm{~W}$ & 7647 & 7367 & 7253 & 7199 & 7164 & 7146 \\
\hline & $P_{c u 2}, \mathrm{~W}$ & 3769 & 3604 & 3537 & 3505 & 3484 & 3474 \\
\hline & Torque ripple, $\%$ & 58.79 & 39.2 & 27.44 & 19.6 & 11.76 & 3.92 \\
\hline & $P_{\text {in }}, \mathrm{W}$ & 265300 & 265500 & 265600 & 265600 & 265600 & 265600 \\
\hline & $P F$ & 0.8629 & 0.8725 & 0.8763 & 0.8781 & 0.8794 & 0.88 \\
\hline & $\eta, \%$ & 94.22 & 94.15 & 94.12 & 94.11 & 94.1 & 94.1 \\
\hline & THDi, \% & 26.62 & 17.75 & 12.43 & 8.884 & 5.343 & 1.831 \\
\hline \multirow{8}{*}{$\begin{array}{c}5^{\text {th }} \text { and } 7^{\text {th }} \\
\text { order } \\
\text { harmonic }(\mathrm{H} 5 \\
\& \mathrm{H} 7)\end{array}$} & Weight, $\%$ & 10.61 & 7.07 & 4.949 & 3.52 & 2.1 & 0.63 \\
\hline & $P_{c u l}, \mathrm{~W}$ & 7891 & 7475 & 7306 & 7226 & 7173 & 7146 \\
\hline & $P_{c u 2}, \mathrm{~W}$ & 3913 & 3668 & 3568 & 3521 & 3490 & 3474 \\
\hline & Torque ripple, $\%$ & 17.14 & 11.42 & 7.997 & 5.688 & 3.393 & 1.018 \\
\hline & $P_{\text {in }}, \mathrm{W}$ & 265500 & 265600 & 265600 & 265600 & 265600 & 265600 \\
\hline & $P F$ & 0.8832 & 0.8814 & 0.8807 & 0.8804 & 0.8802 & 0.88 \\
\hline & $\eta, \%$ & 94.16 & 94.13 & 94.11 & 94.11 & 94.1 & 94.1 \\
\hline & THDi, \% & 32.33 & 21.55 & 15.09 & 10.73 & 6.414 & 1.972 \\
\hline \multirow{8}{*}{$\begin{array}{l}11^{\text {th }} \text { order } \\
\text { harmonic } \\
(\mathrm{H} 11)\end{array}$} & Weight, \% & 15 & 10 & 7 & 5 & 3 & 1 \\
\hline & $P_{c u l}, \mathrm{~W}$ & 7348 & 7234 & 7188 & 7166 & 7152 & 7144 \\
\hline & $P_{c u 2}, \mathrm{~W}$ & 3593 & 3526 & 3499 & 3486 & 3477 & 3473 \\
\hline & Torque ripple, $\%$ & 37.19 & 24.8 & 17.36 & 12.4 & 7.439 & 2.48 \\
\hline & $P_{\text {in }}, \mathrm{W}$ & 264500 & 265100 & 265400 & 265500 & 265600 & 265600 \\
\hline & $P F$ & 0.8896 & 0.8843 & 0.8821 & 0.8811 & 0.8804 & 0.8801 \\
\hline & $\eta, \%$ & 94.49 & 94.27 & 94.18 & 94.14 & 94.11 & 94.1 \\
\hline & THDi, \% & 16.92 & 11.28 & 7.904 & 5.655 & 3.412 & 1.215 \\
\hline \multirow{8}{*}{$\begin{array}{l}13^{\text {th }} \text { order } \\
\text { harmonic } \\
(\mathrm{H} 13)\end{array}$} & Weight, \% & 15 & 10 & 7 & 5 & 3 & 1 \\
\hline & $P_{c u l}, \mathrm{~W}$ & 7289 & 7208 & 7175 & 7160 & 7149 & 7144 \\
\hline & $P_{c u 2}, \mathrm{~W}$ & 3558 & 3511 & 3491 & 3482 & 3476 & 3473 \\
\hline & Torque ripple, $\%$ & 31.56 & 21.04 & 14.73 & 10.52 & 6.312 & 2.104 \\
\hline & $P_{\text {in }}, \mathrm{W}$ & 264700 & 265200 & 265400 & 265500 & 265600 & 265600 \\
\hline & $P F$ & 0.8703 & 0.8757 & 0.8779 & 0.879 & 0.8796 & 0.88 \\
\hline & $\eta, \%$ & 94.45 & 94.25 & 94.17 & 94.14 & 94.1 & 94.1 \\
\hline & THDi, \% & 14.33 & 9.556 & 6.697 & 4.794 & 2.899 & 1.057 \\
\hline \multirow{8}{*}{$\begin{array}{c}11^{\text {th }} \text { and } 13^{\text {th }} \\
\text { order } \\
\text { harmonic } \\
(\mathrm{H} 11 \& \mathrm{H} 13)\end{array}$} & Weight, \% & 10.61 & 7.07 & 4.949 & 3.52 & 2.1 & 0.63 \\
\hline & $P_{c u l}, \mathrm{~W}$ & 7319 & 7221 & 7182 & 7163 & 7150 & 7144 \\
\hline & $P_{c u 2}, \mathrm{~W}$ & 3576 & 3518 & 3495 & 3484 & 3476 & 3473 \\
\hline & Torque ripple, $\%$ & 4.96 & 3.305 & 2.314 & 1.646 & 0.9818 & 0.2945 \\
\hline & $P_{\text {in }}, \mathrm{W}$ & 264600 & 265200 & 265400 & 265500 & 265600 & 265600 \\
\hline & $P F$ & 0.8801 & 0.88 & 0.88 & 0.88 & 0.88 & 0.88 \\
\hline & $\eta, \%$ & 94.47 & 94.26 & 94.18 & 94.14 & 94.11 & 94.1 \\
\hline & THDi, $\%$ & 15.68 & 10.45 & 7.323 & 5.218 & 3.134 & 1.035 \\
\hline
\end{tabular}

negative-sequence harmonic, the torque ripple and power factor in the asynchronous motor has a negligible increase.

Through the analysis results, in order for electric excavators or more specifically, asynchronous motors to operate effi- ciently with little heat loss, it is necessary to limit the voltage THD in the distribution grid or limiting the presence of the fifth harmonic in the distribution grid. 


\section{Literatura - References}

1. Bui, X. N., \& Drebenstedt, C. (2004). Use of hydraulic backhoe excavator in Vietnam open pit coal mines. In Mine Planning and Equipment Selection 2004: Proceedings of the Thirteenth International Symposium on Mine Planning and Equipment Selection, Wroclaw, Poland, 1-3 September 2004 (p. 197). CRC Press.

2. Hai, D. V. (2016). Optimization of truck and shovel for haulage system in the cao son mine, Viet Nam using queuing theory (Doctoral dissertation, Prince of Songkla University).

3. Zenkov, I. V., Vokin, V. N., Kiryushina, E. V., \& Raevich, K. V. (2018). Remote monitoring data on opencast mining and disturbed land ecology in the bakal iron ore field. Eurasian Mining, 2018(2), 29-33.

4. Х Хисматуллин, Э. В. (2018). Модернизация электропривода экскаватора ЭКГ-5 (Doctoral dissertation, ЮжноУральский государственный университет).

5. Lee, C. Y. (1999). Effects of unbalanced voltage on the operation performance of a three-phase induction motor. IEEE Transactions on Energy Conversion, 14(2), 202-208.

6. Mirabbasi, D., Seifossadat, G., \& Heidari, M. (2009, November). Effect of unbalanced voltage on operation of induction motors and its detection. In 2009 International Conference on Electrical and Electronics Engineering-ELECO 2009 (pp. I-189). IEEE.

7. Kersting, W. H., \& Phillips, W. H. (1997). Phase frame analysis of the effects of voltage unbalance on induction machines. IEEE Transactions on Industry Applications, 33(2), 415-420.

8. Gnacinski, P. (2008). Effect of unbalanced voltage on windings temperature, operational life and load carrying capacity of induction machine. Energy Conversion and Management, 49(4), 761-770.

9. Wang, Y. J. (2001). Analysis of effects of three-phase voltage unbalance on induction motors with emphasis on the angle of the complex voltage unbalance factor. IEEE Transactions on energy conversion, 16(3), 270-275.

10. Dekhandji, F. Z., Refoufi, L., \& Bentarzi, H. (2017). Quantitative assessment of three phase supply voltage unbalance effects on induction motors. International Journal of System Assurance Engineering and Management, 8(1), 393406.

11. Ding, X., \& Mi, C. C. (2011). Impact of inverter on losses and thermal characteristics of induction motors. International Journal of Power Electronics, 3(6), 641-651.

12. Yacamini, R., \& Chang, S. C. (1995). Noise and vibration from induction machines fed from harmonic sources. IEEE Transactions on energy conversion, 10(2), 286-292.

13. Mashinform. Двигатели асинхронные типа A4-355, AO4-355, [online]. Accessed 28.7.2020. Available at: https:// electro.mashinform.ru/dvigateli-asinhronnye-raznyh-tipov/dvigateli-asinhronnye-tipa-a4-355-ao4-355-obj4033. html.

14. Natarajan, R., \& Misra, V. K. (1989). Parameter estimation of induction motors using a spreadsheet program on a personal computer. Electric power systems research, 16(2), 157-164.

15. Mathworks. Asynchronous Machine, [online]. Accessed 28.7.2020. Available at: https://www.mathworks.com/help/ physmod/sps/powersys/ref/asynchronousmachine.html.

16. Beleiu, H. G., Maier, V., Pavel, S. G., Birou, I., Pică, C. S., \& Dărab, P. C. (2020). Harmonics Consequences on Drive Systems with Induction Motor. Applied Sciences, 10(4), 1528.

\section{Wpływ jakości napięcia na wydajność silnika asynchronicznego koparki EKG w kopalniach od- krywkowych Vinacomin \\ Obecnie, EKG sa powszechne koparki stosowane w kopalnictwie odkrywkowym Wietnamu. Sieć elektryczna $6 k V$ w kopalniach odkrywkowych ma takie cechy, jak długie linie wychodzące, zastosowanie sprzętu o dużej mocy, wiele odgatęzień co obniża jakość energii dostarczanej do koparek EKG, skutkując wzrost strat mocy, co znaczaco wplywa na wydajność koparek. Dotychczasowe bada- nia jakości energii dostarczanej do koparki często wskazywały tylko na odchylenia napięcia. W artykule, przeanalizowano wpływ napięcia niesinusoidalnego na straty mocy silników elektrycznych stosowanych w koparkach elektrycznych EKG w górnictwie odkry- wkowym w oparciu o metodę analizy elektromagnetycznej i weryfikacji w oprogramowaniu symulacyjnym}

Słowa kluczowe: jakość energii, napięcie harmoniczne, napięcie niesinusoidalne, koparki EKG 